\title{
PENERAPAN FACE SHIELD BAGI TENAGA MEDIS UNTUK MENANGANI PASIEN COVID-19 DI KOTA BATU JAWA TIMUR
}

\author{
Mochamad Arif Irfai $^{1}$, Muchlis Arif ${ }^{2}$, Nova Kristiana ${ }^{3}$, I Made Arsana \\ ${ }^{1,4}$ Jurusan Teknik Mesin Fakultas Teknik Universitas Negeri Surabaya \\ ${ }^{2}$ Jurusan Seni rupa Fakultas Bahasa dan Seni Universitas Negeri Surabaya \\ ${ }^{3}$ Jurusan Desain Fakultas Bahasa dan Seni Universitas Negeri Surabaya \\ 1arifirfai@unesa.ac.id \\ ${ }^{2}$ muchlisarif@unesa.ac.id \\ 3novakristiana@unesa.ac.id \\ 4madearsana@unesa.ac.id
}

\begin{abstract}
The purpose of this activity is to assist the government in providing and distributing face shields for medical personnel at referral hospitals to treat covid-19 patients. At first we analyzed the problems with partners (hospitals and community health centers). The results of the analysis show that hospitals and health centers lack a helmet-face shield for medical personnel to treat covid-19 patients. Based on the results of discussions and requests from the partner. Then the design is carried out to manufacture a helmet-face shield. There are 2 PPE made, The first type is only a face shield and the second type is obtained a helmet design that is equipped with a face shield or can be called a helmet-face shield. At the end of the activity, questionnaires were distributed to respondents consisting of doctors, nurses and other medical personnel. Respondents were selected randomly in health facilities in Batu, East Java. The response from medical personnel has generally been positive. This can be seen from the questionnaires distributed to respondents. More than $90 \%$ of the results of the questionnaire stated that helmet-face shield and face shield products could be accepted by health workers.
\end{abstract}

Keywords: covid-19, helm-face shield, scarcity of PPE, hospital and medical personnel

\begin{abstract}
Abstrak: Tujuan dari kegiatan ini adalah membantu Pemerintah dalam hal penyediaan dan pendistribusian face shield bagi tenaga medis di Rumah Sakit rujukan untuk menangani pasien covid-19. Pada awalnya kita menganalisa permasalahan pada mitra (rumah sakit dan puskesmas). Hasil analisa diketahui bahwa rumah sakit dan puskesmas kekurangan helm-face shield bagi tenaga medis untuk menangani pasien covid-19. Berdasarkan hasil diskusi dan permintaan tim mitra, maka dilakukan perancangan untuk pembuatan helm-face shield. Ada 2 APD yang dibuat, Tipe yang pertama hanya berupa face shield saja dan tipe yang kedua diperoleh desain helm yang dilengkapi dengan face shield atau bisa disebut helm-face shield. Pada akhir kegiatan dilakukan pembagian kuesioner kepada responden yang terdiri dari tenaga dokter, perawat dan tenaga medis lainnya. Pemilihan responden dilakukan secara acak di fasilitas Kesehatan yang ada di kota Batu Jawa Timur. Respon dari tenaga medis secara umum menunjukkan hasil yang positif. Hal ini terlihat dari kuesioner yang dibagikan kepada responden. Lebih dari $90 \%$ hasil kuesioner bahwa produk helm-face shield maupun face shield bisa diterima oleh tenaga Kesehatan.
\end{abstract}

Kata kunci: covid-19, helm-face shield, kelangkaan APD, rumah sakit dan tenaga medis

\section{Pendahuluan}

Corona Virus Disease 2019 atau dikenal covid 19 merupakan penyakit yang disebabkan oleh novel coronavirus (SARS-CoV-2). Penyakit ini menyerang sistem pernapasan manusia dan dapat menyebabkan kematian penderitanya. Penularan penyakit covid 19 ini terjadi antar masuia dengan manusia. Virus ini masuk ke tubuh manusia melalui hidung, mata atau mulut dengan perantaraan media yang sebelumnya telah terkontaminasi virus SARS-CoV-2. Masa inkubasi virus covid 19 ini berkisar 2 sampai 14 hari. Penyakit covid 19 sampai saat ini belum ditemukan obatnya. Jumlah penderita yang terinfeksi virus covid 19 terus bertambah dari hari ke hari sejak teridentifikasi akhir tahun 2019 di Wuhan, China. 
2 |Mohammad Arif Irfai, dkk : Penerapan face shield bagi tenaga medis...

Salah satu upaya pemerintah Indonesia dengan menunjuk beberapa Rumah Sakit sebagai rumah sakit rujukan penanganan pasien covid 19. Dalam perjalanannya, rumah sakit yang telah ditunjuk oleh pemerintah sebagai rumah sakit rujukan untuk menangani pasien covid 19 mengalami kekurangan fasilitas APD (Alat Pengaman Diri) bagi dokter, perawat dan tenaga medis. Salah satu APD yang diperlukan saat ini adalah face shield. Persediaan APD yang minim menyebabkan beberapa dokter dan tenaga medis terinfeksi virus covid 19. Beberapa diantara dokter dan tenaga medis dikabarkan meninggal akibat terinfeksi virus covid 19.

Universitas Negeri Surabaya sebagai salah satu Lembaga pemerintah ikut aktif dalam membantu Pemerintah menangani penanggulangan penyebaran penyakit covid 19. Salah satu upaya yang di lakukan Unesa melalui dharma Pengabdian Kepada Masyarakat berupaya untuk membantu penyediaan Alat Pengaman Diri (APD) bagi tenaga medis di Rumah Sakit yang menangani pasien covid 19.

\section{Metode}

Mitra pada kegiatan ini adalah Rumah Sakit dan Puskemas di Kota Batu Jawa Timur. Waktu pelaksanaan kegiatan bulan April-Mei 2020. Metode yang akan diterapkan pada kegiatan ini adalah awalnya kita menganalisa permasalahan yang terjadi di rumah sakit serta fasilitas kesehatan seperti Puskesmas yang ada di masyarakat. Hasil analisa permasalahan diketahui bahwa rumah sakit-rumah sakit memerlukan APD berupa helm-face shield untuk tenaga medis (dokter, perawat dan tenaga medis) bagi penanganan pasien covid 19. Minimnya kebutuhan APD bagi tenaga medis disebabkan pada saat bersamaan permintaan rumah sakit terhadap face shield juga meningkat. Permintaan face shield yang bertambah tidak sebanding dengan produsen yang memproduksi atau membuat face shield. Tim pengusul melalui LPPM dan UCC melakukan pendataan pada rumah sakit-rumah sakit yang mengalami kekurangan APD seperti face shield. Hasil analisa dilakukan untuk menentukan prioritas distribusi APD berupa face shield agar stok APD yang berupa face shield dipastikan cukup untuk menangani pasien covid 19.

Hasil diskusi antara mitra (rumah sakit) dengan tim pengusul didapatkan beberapa masukan mengenai desain dan bentuk face shield yang aman dan nyaman bagi para medis. Hasil diskusi juga diperoleh kesepakatan untuk pembuatan menjadi 2 tipe. Tipe yang pertama hanya berupa face shield saja. Tipe yang pertama ini diperuntukkan bagi para medis yang menangani pasien di dalam ruangan perawatan atau ruangan pemeriksaan awal. Sedangkan tipe yang kedua diperoleh desain helm yang dilengkapi dengan face shield atau biasa ditulis helm-face shield. Tipe yang kedua ini diperuntukkan bagi para medis yang menangani pasien yang berada di luar lapangan seperti pemulasaran, perawatan jenasah akibat penyakit covid 19 serta pemakaman pasien yang meninggal akibat penyakit covid 19 .

Hasil diskusi selanjutnya dicatat dan diinventarisir oleh tim pengusul. Ketua tim pengusul bertugas mengkoordinir dan membuat jadwal seluruh kegiatan yang akan dilakukan oleh anggota tim pengusul serta mengkoordinasikan ditribusi APD face shield ke mitra, Anggota tim pengusul 1 bersama mahasiswa bertugas memastikan kebutuhan material dan proses produksi pembuatan helm-face shield maupun face shield tidak mengalami keterlambatan serta selesai tepat waktu sesuai yang direncanakan. Anggota tim pengusul 2 bersama mahasiswa bertugas membuat desain face shield dan membuat stiker yang akan ditempel pada helm-face shield maupun face shield. Untuk menjamin ketersediaan APD berupa helm-face shield maupun face shield maka akan 
3 |Mohammad Arif Irfai, dkk : Penerapan face shield bagi tenaga medis...

dilakukan monitoring dan evaluasi pasca kegiatan penyerahan APD helm-face shield maupun face shield. Penyebaran kuesioner dilakukan kepada responden. Pemilihan responden dilakukan secara sampling.

\section{Hasil dan Pembahasan}

1. Pembuatan dan penyerahan face shield maupun helm-face shield kepada Mitra Desain face shield dan helm-face shield yang dikembangkan seperti ditunjukkan pada gambar dibawah ini :
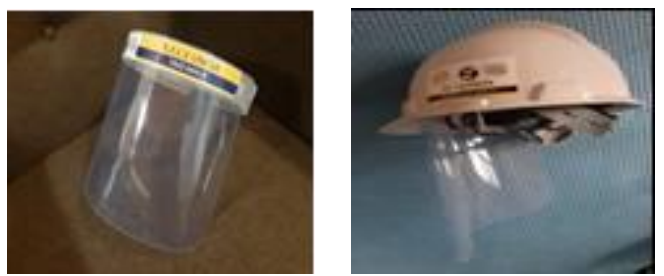

Gambar 5. a. desain face shield, b. desain helm-face shield

Bagian-bagian dari helm-face shield terdiri dari : helm sebagai pelindung kepala, adjuster sebagai pengatur ikatan karet elastis, karet elastis untuk mengencangkan dan melonggarkan ikatan pada kepala, mika bening berfungsi sebagai penutup/pelindung wajah. Bahan-bahan yang digunakan dalam pembuatan helm-face shield terdiri dari helm, mika astralon bening dan garis-garis. Sedangkan alat-alat yang digunakan bor listrik, kabel ties, gunting dan alat ukur. Proses pembuatan face shield melalui tahapan berikut ini : a. Ukurlah mika bening $28 \times 22 \mathrm{~cm}$, b. potonglah mika tersebut perlahan-lahan, c. tumpulkan bagian bawah dengan menggunting rapi, d. ambillah mika garis-garis, e. ukurlah mika garis-garis masing-masing $50 \mathrm{~cm} \mathrm{x} 3,5 \mathrm{~cm}$ dan 42 $\mathrm{cm} \times 3,5 \mathrm{~cm}$, f. kemudian potonglah pelan-pelan, g. rapikan bagian kanan-kiri, h. rapikan pula bagian atas bawah dari mika garis-garis, i. bagian mika yang garis-garis dengan ukuran $42 \mathrm{~cm} \mathrm{x} \mathrm{3,5} \mathrm{cm}$ ditempelkan ke bagian depan mika, j. lubangi mika garis-garis dengan bor listrik, k. rekatkanlah mika bening dengan mika garis menggunakan kabel ties, 1. jarak pinggir mika bening dengan ujung luar mika garis-garis $7 \mathrm{~cm}, \mathrm{~m}$. kemudian ikat kuat antara mika bening dengan mika garis-garis, n. rapikan kedua bagian mika bening dengan mika garisgaris yang telah diikat kuat dengan memotong kabel ties yang tersisa, 0 . menggabung bagian depan dengan bagian belakang (ukuran mika garis $50 \mathrm{~cm}$ x 3,5 $\mathrm{cm})$. p. dilubangi menjadi satu kemudian diikat dengan kabel ties, q. memasang knop stop dengan tali kur pada bagian belakang, r. perhatikan dengan seksama cara memasang knop stop, s. ikat dengan kuat kemudian bakar bagian ujung, t. face shield telah selesai, u. tempel bagain depan face shield dengan stiker.

Proses pembuatan helm-face shield melalui tahapan sebagai berikut : a. masukkan face shield pada bagian dalam helm, b. melubangi ikatan helm sebagai lubang penyambung dengan mika, c. memasang face shield pada bagian dalam helm, d. helm-face shield telah selesai e. helm-face shield ditempeli stiker $\mathrm{f}$. Pengemasan face shield maupun helmface shield ke dalam kardus.

Helm-face shield maupun face shield yang telah dipacking siap diserakan ke mitra. Berikut adalah mitra dalam PKM : a. Rumah Sakit Baptis Batu, b. Puskesmas Batu, c. Beberapa Rumah Sakit di Jawa Timur. Adapun kalangan yang telah menggunakan produk helm-face shield maupun face shield dokter, perawat, staf rumah sakit mupun puskemas serta civitas akademika Unesa.

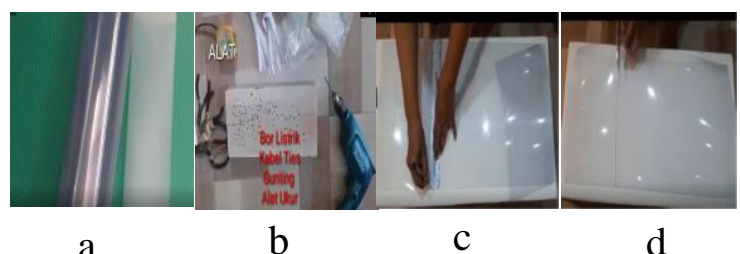

b

c 
4 |Mohammad Arif Irfai, dkk : Penerapan face shield bagi tenaga medis...
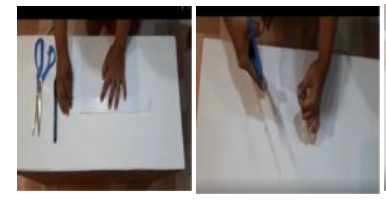

e

f

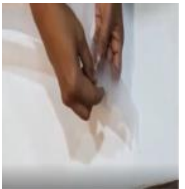

g

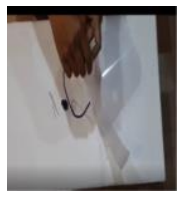

h

Gambar 6. Proses pembuatan face shield a. mika bening $b$. alat yang digunakan c. pengukuran mika bening $d$. pemotongan mika bending e. pemotongan mika garis $f$. penggabungan mika bening (bagian depan) dengan mika garis-garis (bagian belakang) g. pengikatan dengan menggunakan tali ties $\mathrm{h}$. memasang knop stop pada bagian belakang

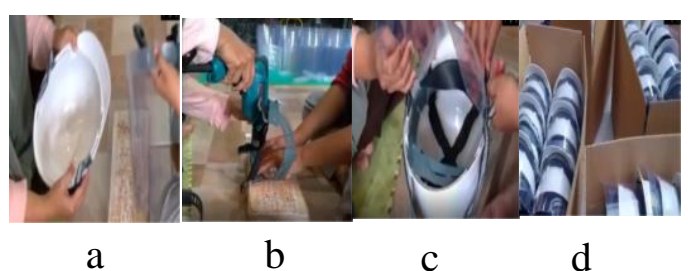

Gambar 7. Proses pembuatan helm-face shield a. memasukkan face shield ke dalam bagian dalam helm b. melubangi ikatan helm dengan mika c. memasang face shield pada bagian dalam helm d. Helm-face shield siap diserahkan

30 responden yang kesemuanya adalah tenaga Kesehatan (dokter, perawat dan staff rumah sakit) yang berkerja pada rumah sakit maupun puskesmas. Metode pengambilan data dilakukan dengan sampel. Responden terdiri dari 11 orang berjenis kelamin pria dan 19 orang berjenis kelamin wanita.

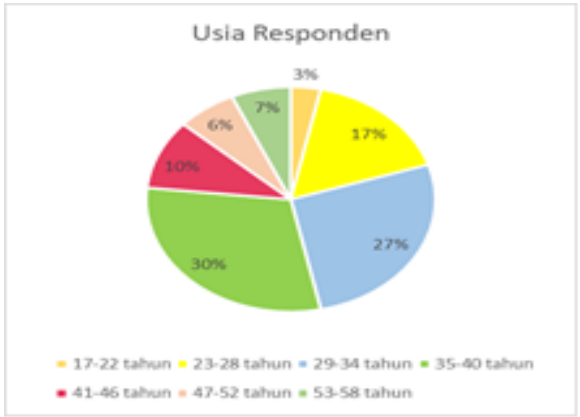

Gambar 8. Diagram sebaran usia responden

Usia dari para responden bervariasi mulai dari yang paling muda berusia 21 tahun dan paling tua 54 tahun. Responden yang berusia 17-22 tahun sebanyak 1 orang (3\%), 5 orang berusia 23-28 tahun $(17 \%), 8$ orang berusia $29-34$ tahun $(27 \%), 9$ orang berusia $35-40$ tahun $(30 \%), 3$ orang berusia $41-46$ tahun (10\%), 2 orang berusia $47-52$ tahun $(6 \%)$ dan 2 orang berusia 53-58 tahun (7\%)

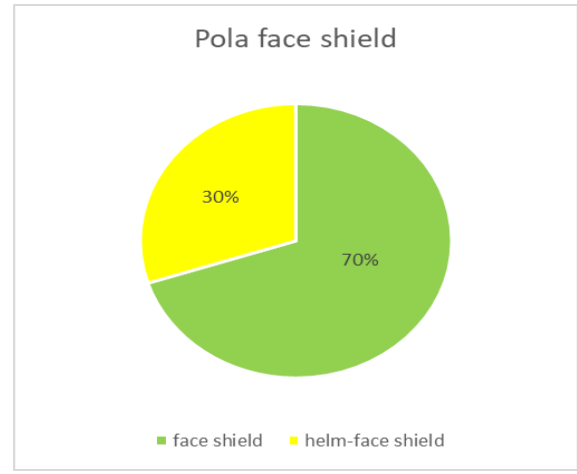

Gambar 9. Pola dari APD yang disukai oleh tenaga kesehatan

Berdasarkan daftar pertanyaan instrumen yang diberikan kepada responden terkait dengan pola face shield yang disukai, dari 30 responden yang disurvey 21 responden atau sekitar $70 \%$ menjawab face shield dan 9 responden (30\%) menjawab helm-face shield. Sedangkan pada desain face shield, seluruh responden (30 responden) setuju bahwa desain face shield untuk medis saat ini sudah bagus sesuai standar WHO. 
5 |Mohammad Arif Irfai, dkk : Penerapan face shield bagi tenaga medis...

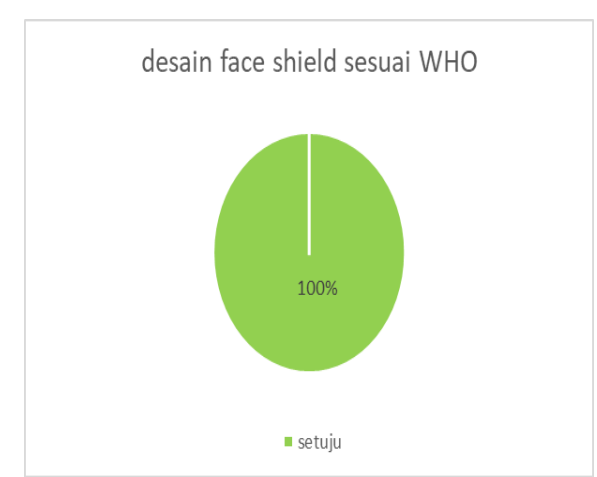

Gambar 10 Pendapat responden terkait face shield sesuai standar WHO

Pertanyaan instrumen selanjutnya mengenai bentuk helm-face shield maupun face shield yang dipakai sudah sesuai (tidak terlalu kencang dan tidak terlalu longgar) sebanyak 28 responden setuju dengan bentuk dengan helm-face shield saat ini dan 2 responden tidak setuju dengan bentuk helm-face shield saat ini.

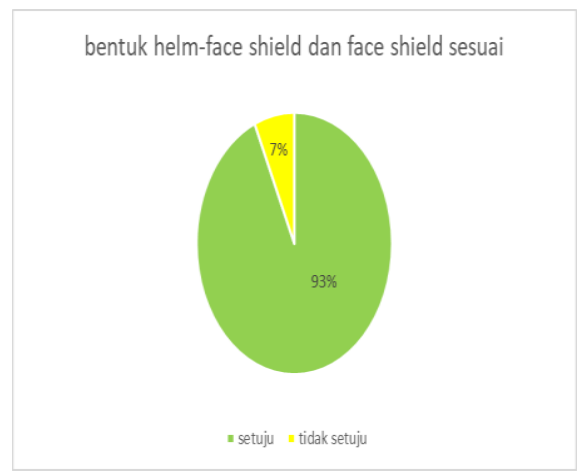

Gambar 11.Pendapat responden terkait bentuk helm-face shield dan face shield

Pertanyaan instrumen berikutnya terkait, apakah face shield yang digunakan nyaman dan aman ketika digunakan untuk berkerja, seluruh responden (100\%) setuju face shield nyaman dan aman saat digunakan untuk berkerja.

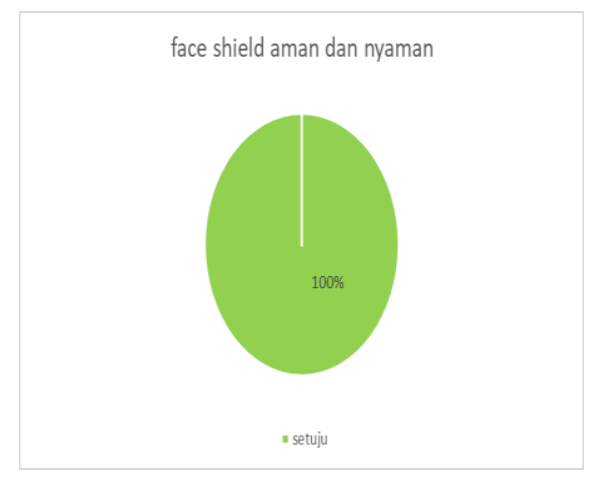

Gambar 12.Pendapat responden terkait keamanan dan kenyamanan face shield

Selanjunya, seluruh responden (30 responden) sepakat bahwa minimnya penggunaan Alat Pelindung Diri (APD) helm-face shield maupun face shield merupakan salah satu factor penyebab tertularnya covid-19 pada tenaga kesehatan (Nakes). Masukan atau saran dari responden terkait produk helm-face shield maupun face shield sebaiknya antara mika pelindung dengan adjuster tidak ada ruang atau space terbuka.

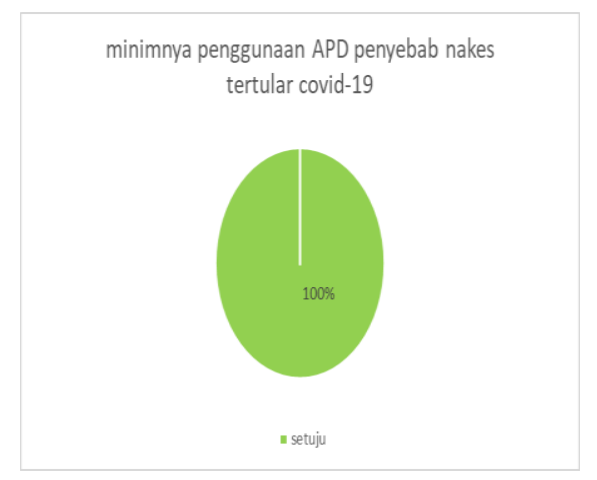

Gambar 13.Pendapat responden terkait minimnya penggunaan APD merupakan salah satu penyebab tertularnya covid-19

\section{Simpulan}

Pembuatan helm-face shield maupun face shield melalui tahapan sebagai berikut: persiapan bahan dan alat, prepare mika bening dan garis-garis, perakitan tali ke adjuster, face shield 
6 |Mohammad Arif Irfai, dkk : Penerapan face shield bagi tenaga medis...

telah jadi kemudaian dilanjutkan dengan perakitan helm-face shield. Respon penggunaan helm-face shield maupun face shield sebagai pelindung tenaga kesehatan ketika menangani pasien covid-19 secara umum menunjukkan respon positif. Hal ini terlihat dari hasil kuesioner (lebih dari 90\%) responden menyatakan bahwa produk helm-face shield maupun face shield layak digunakan sebagai APD bagi tenaga kesehatan ketika menangani pasien covid-19

\section{Daftar Pustaka}

Husein A., Sadika F. dan Yunidar.(2018). Pengembangan Sistem Penyetelan Ukuran Kepala pada Helm Las, eProceeding of Art \& design Vol. 5 No. 3 Desember 2018 ISSN : 23559349

Kampf D, Todt S., Pfaender., E.(2020). Steinnnmann, Persistence of coronaviruses on inanimate surfaces and their inactivation with biocidal agents, Journal of Hospital Infection 104, pp.246-251

Mary L. Mccausland, Face shield.(1998). United States Patent, Patent Number 5.765.223

Yan Bai, Lingsheng Yao, Tao Wei, Fei Tian, Dong-Yan Jin, Lijuan Chen, Meiyun Wang.(2020). Presumed Asymptomatic Transmission of COVID 19, Reseach Letter

Yurianto A. (2020, April). Update: Kasus Covid-19 di Indonesia ada 4.839, Bertambah 282 orang, Diunduh dari: http://www.nasional.kompas.com/rea d/2020/04/14/16152541 tanggal 15 April 2020

IDI (2020, April). Enam Dokter Meninggal Diduga Terpapar Corona, Diunduh dari: http://www.cnnindonesia.com/nasion al/20200322202727-20-485844 tanggal 14 April 2020 